\title{
Comparative Analysis of Financing for Small and Medium-Sized Enterprises in the Visegrad Group
}

\author{
Veronika Vrablova ${ }^{1, *}$ \\ ${ }^{1}$ University of Zilina, Faculty of Operation and Economics of Transport and Communications, \\ Department of Economics, Univerzitna 1, 01026 Zilina, Slovakia
}

\begin{abstract}
.
Research background: Small and medium-sized enterprises form the backbone of any national economy. Therefore, sources of financing are important for the enterprise's growth around the world. Finance for enterprises can be divided into classic and alternative. Recently, alternative ways of financing experienced a boom, especially venture capital, business angels, and crowdfunding. Although this type of funding is well known around the world, there are difficulties in using alternative financing among the Visegrad group. Moreover, there are lots of other factors curbing the expansion of enterprises.

Purpose of the article: The purpose of this paper is to identify and compare sources of financing for small and medium-sized enterprises among the Visegrad group with focus on alternative financing. Visegrad group consists of the Slovak Republic, the Czech Republic, the Hungary, and the Poland. This paper presents an overview of available financing for small and medium-sized enterprises among the Visegrad group.

Methods: For analysis, we used data from the the Survey on the access to finance for enterprises in 2019. Moreover, we also did hypothesis testing to compare the usage of financing through bank overdraft in the year 2019.

Findings \& Value added: We have reached several conclusions. Firstly, this paper suggests that classic sources of financing are used more than alternative ways, from which the bank loans and leasing are used the most. Secondly, the best condition of financing among countries of the Visegrad group is in Poland, but also other countries have huge potential. And finally, financing of enterprises is not the main issue causing difficulties in making business.
\end{abstract}

Keywords: venture capital; small and medium-sized enterprises; sources of financing; statistical hypothesis testing; Visegrad group

JEL Classification: $C 12 ; D 24 ; G 24$

${ }^{*}$ Corresponding author: veronika.vrablova@,stud.uniza.sk 


\section{Introduction}

Small and medium-sized (SME) enterprises are an integral part of every economy. Their share in the country's produced GDP and the share in the number of jobs created is notable in each economy. In the Visegrad group (V4), SMEs contribute more than half of GDP and employ more than $60 \%$ of the total workforce. SMEs are also more involved in job creation than large companies [2]. However, these SMEs often face funding barriers due to insufficient collateral, unclear information, risk and high transaction costs for capital acquirers [9, 13]. SME development is a sign of a country's macroeconomic stability [7].

Within the European Union, small and medium-sized enterprises are the driving force of the economy, accounting for up to $99.8 \%$ of all enterprises and accounting for $54.8 \%$ of total value-added, which is more than $€ 4$ trillion.

Due to globalization, the issue of financing for small and medium-sized enterprises is largely argued around the world. Every company necessarily needs enough funds for its development, the amount of which depends on the available sources of financing. The most suitable way for financing in Czechia seems to be the bank and other loans because Czech SME does not consider indebtedness to be high risk in doing business [12]. In terms of funding enterprises with longer history prefer financing from foreign sources [6]. On the other side, the condition of bank products such as loans, credits, guarantees depends on the effectivity of the banking system. According to Balcerzak et al. (2017), efficient banking sector have countries in the Eurozone than countries that have not yet applied for the euro [4].

Outside the EU, we can see different developments in small and medium-sized enterprises. In Canada, for example, SMEs are an important determinant of the national economy. In total, the small business sector employs 6 out of 10 working Canadians. Within the US, the main problem for SMEs is not access to capital as such, but access to capital that individual SMEs can afford under given conditions [15].

One of the fastest-growing economies in the world is India, where the SME sector is less developed. However, the SME sector is important to the Indian economy, as they account for more than a third of total GDP. Fourth Census statistics conducted in 2009 for the SME sector show that up to $92.77 \%$ of enterprises do not rely on external financing; $5.18 \%$ use funds obtained from banks or other institutions and the rest use the funds of nonbanking institutions. This suggests that SMEs are largely dependent on internal and informal sources of funding $[1,11$,$] . External financing is not used due to its high cost and$ its lack [8].

The situation in the Asian continent is very similar. Most of the Chinese companies take for barrier lack available capital to finance their long-term requirements [10, 16]. China, as a developing country, faces the problem of lower penetration of available financial services for SMEs than in developed economies [5]. However, small and medium-sized enterprises are also a significant part of the national economy here. According to a 2013 report by the China National Statistics Committee, SMEs employ up to $80 \%$ of the local population, account for $50 \%$ of taxes collected, and generate up to $60 \%$ of total GDP [14]. In Japan, SMEs also play an important role, as up to $72 \%$ of the population is involved in these enterprises [3].

The issue of financing small and medium-sized enterprises is topical especially at present, when the whole world is facing a crisis. Businesses have lost many of their customers and suppliers and need funding to save their business.

On the other hand, the high development of the hi-tech industry and the related emergence of constantly new technological and innovative start-ups that need financial capital for research and development of their products can be seen at present. These 
companies often look for alternative financing options, such as venture capital, investments from business angels, or various types of collective financing.

However, regulations as well as incentives from the state affect the availability and possibilities of financing for small and medium-sized enterprises, which are based on the development of the business activity. With the current development of new companies in particular with innovative ideas, there is a growing need to increase the availability of alternative forms of financing, as traditional forms such as credit and leasing are in terms of cost and security of assets do not require financing from these companies.

This paper is focused on the issue of financing small and medium-sized enterprises in the V4 countries. With the issue of available funding deal several institutions such as the European Commission (EC) and the European Central Bank (ECB). ECB and EC publish a survey focused on companies' access to finance called the SAFE survey every year. The aim of this paper is a comparison of available financing for SMEs based on SAFE survey data with a focus on alternative financing such as business angel's investment and crowdfunding and the second aim is hypothesis testing on selected financing.

\section{Methods}

We made an analysis of partial data from the SAFE survey and from the OECD evaluation report. Moreover, to describe the situation in alternative financing we also used outputs from Statistical Summary published by European Business Angels Network and Crowdfunding fact sheets published by European Crowdfunding Network. Consequently, we used partial data from SAFE in testing statistical hypotheses to test the usage of bank overdrafts as a way of finance among V4 countries.

Examined sample

In 2019, a total of 15,427 European small and medium-sized enterprises took part in the survey, of which 2,351 were enterprises from the V4 countries. From Slovakia, 460 SMEs participated in the survey, in the Czech Republic, it was 350, in Hungary 450 and in the Poland 1,091 small and medium-sized enterprises.

Table 1. A sample of enterprises from V4 countries surveyed in SAFE survey.

\begin{tabular}{|c|c|c|c|c|c|c|c|c|}
\hline \multirow{2}{*}{$\begin{array}{c}\text { Size } \\
\text { category }\end{array}$} & \begin{tabular}{c} 
Czech republic \\
\cline { 2 - 8 } \\
$\begin{array}{c}\text { Number } \\
\text { of } \\
\text { enterprise } \\
\text { s }\end{array}$
\end{tabular} & $\begin{array}{c}\text { Hungary } \\
\text { share }\end{array}$ & $\begin{array}{c}\text { Number } \\
\text { of } \\
\text { enterprise } \\
\text { s }\end{array}$ & $\begin{array}{c}\text { \% } \\
\text { share }\end{array}$ & $\begin{array}{c}\text { Number } \\
\text { of } \\
\text { enterprise } \\
\text { s }\end{array}$ & $\begin{array}{c}\text { Poland } \\
\text { share }\end{array}$ & $\begin{array}{c}\text { Number } \\
\text { of } \\
\text { enterprise } \\
\text { s }\end{array}$ & $\begin{array}{c}\% \\
\text { share }\end{array}$ \\
\hline $\begin{array}{c}\text { Micro } \\
\text { enterprise } \\
\text { s }\end{array}$ & 162 & $46.2 \%$ & 222 & $49.2 \%$ & 603 & $55.2 \%$ & 267 & $58.0 \%$ \\
\hline $\begin{array}{c}\text { Small } \\
\text { enterprise } \\
\text { s }\end{array}$ & 90 & $25.7 \%$ & 122 & $27.2 \%$ & 207 & $19.0 \%$ & 89 & $19.3 \%$ \\
\hline $\begin{array}{c}\text { Medium } \\
\text { enterprise } \\
\text { s }\end{array}$ & 99 & $28.2 \%$ & 106 & $23.6 \%$ & 281 & $25.8 \%$ & 105 & $22.8 \%$ \\
\hline $\begin{array}{c}\text { SME in } \\
\text { total }\end{array}$ & $\mathbf{3 5 0}$ & $\mathbf{1 0 0 . 0}$ \\
$\mathbf{\%}$
\end{tabular}

For hypothesis testing, we used a one-tailed test on secondary data from the SAFE survey. At first, we were verifying whether the examined sample of SMEs is statistically relevant. We verified the relevance using a sample size calculator, where we choose $95 \%$ as the confidence level, as the confidence interval $5 \%$, and as a population size number of all 
SMEs in each country in 2019 , which were obtained from national statistical offices. The relevant sample size was 384 small and medium-sized enterprises. Secondly, we defined a null and an alternative hypothesis. Thirdly, we determined the significance level $\alpha$. Fourthly, we calculated the share of the examined feature in the sample. Fifthly, we made the calculation of the test criterion, and finally the decision and the result of the test were made - whether to accept or deny the null hypothesis.

We compared the test criterion with the critical value of the normalized normal distribution, according to inequation:

$$
\mathrm{T}>\mathrm{z}(1-\alpha)
$$

The calculation of the test criterion is based on the equation:

$$
T=\frac{\hat{p}-\pi}{\sqrt{\frac{\pi *(1-\pi)}{n}}}
$$

n $\quad$-total number of SME for a country

$\pi \quad$-constant

$\hat{p} \quad$-share of the examined feature

The condition must be met to perform the test:

$n * \pi \geq 5$ and at the same time $n *(1-\pi) \geq 5$

$\mathrm{n} \quad$-total number of entreprises participating in the survey

$\pi \quad$-constant

We tested four groups of hypotheses focused on the use of financing through the allowed overdraft. For each country, we did test in 2019 with the same level of significance $\alpha=0.05$. We formulated the null hypothesis $\mathrm{H}_{0}$ and alternative one-tailed hypothesis $\mathrm{H}_{1}$ (right-tailed or left-tailed) for each country:

\section{Slovak Republic}

$\mathrm{H}_{0}: 30 \%$ of Slovak small and medium-sized enterprises used financing through the bank overdraft in 2019.

$\mathrm{H}_{1}$ : More than $30 \%$ of Slovak small and medium-sized enterprises used financing through the bank overdraft in 2019.

\section{Czech Republic}

$\mathrm{H}_{0}: 30 \%$ of Czech SME used financing through the bank overdraft in 2019.

$\mathrm{H}_{1}$ : Less than $30 \%$ of Czech SMEs used financing through the bank overdraft in 2019.

\section{Poland}

$\mathrm{H}_{0}$ : In $2019,40 \%$ of Polish small and medium-sized enterprises used an overdraft to finance their activities.

$\mathrm{H}_{1}$ : In 2019, more than $40 \%$ of Polish small and medium-sized enterprises used an overdraft to finance their activities.

\section{Hungary}

$\mathrm{H}_{0}$ : In 2019, 20\% of Hungarian SMEs used the bank overdraft as a source of financing.

$\mathrm{H}_{1}$ : In 2019, less than $20 \%$ of Hungarian SMEs used the bank overdraft as a source of financing.

\section{Results and Discussion}

Based on data from the SAFE survey we find out that access to finance is proving to be the least problem among European Union but also among the V4 group. Within the Slovak Republic, $6.9 \%$ of companies experience problems with financing. In Poland, there are 
even slightly fewer companies, at $6.2 \%$. In Hungary, the availability of capital is the biggest problem among the V4 countries $(8.3 \%)$. Every thirteenth Czech company has a problem with the availability of capital. access to finance is the least barrier defending SME to grow.

In fact, the most important problem for enterprises in the EU is the availability of experienced workers - managers. The lack of experienced managers is the biggest problem for the Slovak Republic when almost every third company faces its shortage. Polish companies perceive the availability of experienced managers as the least problem among the V4 countries.

Problems of SME in 2019

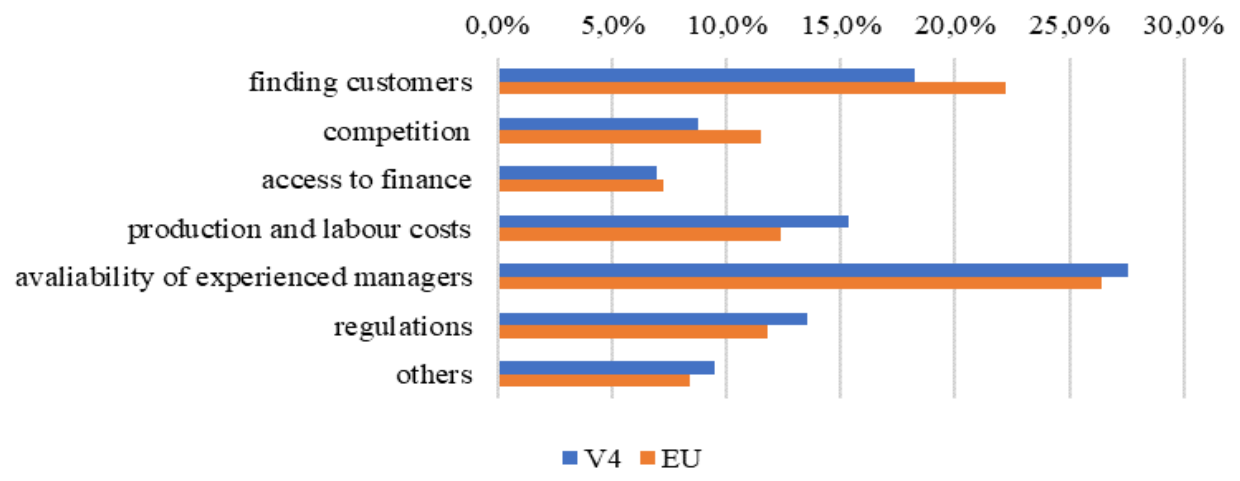

Fig. 1. Problems of SME in 2019.

With many forms of financing offered, the most used source in Europe is classic ways such as bank loans or financial leasing. In Hungary, this funding is used the least because of the high costs for businesses. Banking institutions and leasing companies could focus more on creating cheaper products for SMEs. Surveys also found that SMEs receive an average of $1.5 \mathrm{p} . \mathrm{b}$ a higher annual interest rate on the loan provided than large enterprises.

Another problem that businesses face when applying for a loan is the overly timeconsuming and bureaucratic process. This problem could be eliminated by simplifying the whole loan application process, for example by linking all registers containing information on companies, their creditworthiness, indebtedness, financial statements, and other information directly to the databases of banking institutions, thus eliminating the obligation for companies to document all necessary information, financial statements and documents.

Although bank loans are the most required financing, a large number of small and medium-sized enterprises face rejection by the bank. Bank rejection is mainly associated with insufficient security. Businesses, especially in the early stages of their business, do not have enough assets to guarantee the required loan. The provision of state guarantees or guarantees of state financial institutions is a suitable measure by the state in this case, but on the other hand, there is a risk that the company will go bankrupt and will not be able to repay its loan. It is for this reason that the provision of state guarantees is a lengthy process, and a more appropriate way to help small and medium-sized enterprises could be to promote alternative financing, where the company does not need to guarantee its assets for the funds provided.

Regarding alternative funding, the most used is venture capital or private equity. The main advantages of this financing in V4 countries are a huge selection of VC funds in the Czechia, high concentration of innovative financing in Hungary, high rate of selfconfidence in Poland, and investment opportunities in Slovakia. On the other side, enterprises face a lack of self-confidence when requesting this financing in the Czech 
Republic, lack of information in the Hungary, complicated way of getting this financing in Poland, and little amount of invested capital in the Slovak Republic.

In addition, enterprises have low experiences with another alternative financing such as business angels investment or crowdfunding. Pros of business angels investment are fastgrowing market in V4 countries. Cons are a lower chance to get financing in Czechia, high competition in Hungary, other more available funding in Poland, and lack of Business angels in Slovakia.

Collective funding has recently been proving to be a very promising source of funding. It fills a gap between traditional and alternative financing that the company has failed to obtain for various reasons. The necessary development of this business requires the application of the same rules to collective platforms throughout the V4 group so that a company from each country has equal and fair access to crowdfunding. In 2018, the European Parliament and the European Council issued a regulation on European providers of collective financing services. The aim of this regulation is to extend and facilitate access to finance for start-ups and other innovative SMEs.

The best condition of crowdfunding is in the Czech Republic, where is the biggest choice of CF platforms and the longest history of this financing. However, Czech SME lack platforms based on the investment. Hungary has a huge potential for crowdfunding because of lots of innovative start-ups, which are the main users of this financing. On the other side, the problem can be inadequate legislation for crowdfunding. In Poland there are lots of investments made through this financing. Slovak SME same as Hungarian have big potential for using crowdfunding. On contrary, Slovak enterprises have lower access to this funding.

\section{Hypothesis testing}

Based on formulated hypothesis, we achieved test results from four groups of tests. Sample of Slovak SME was statistically relevant, the condition has been met and the test criterion was calculated as:

$$
T=\frac{0,3478-0,3}{\sqrt{\frac{0,3 *(1-0,3)}{460}}}=2,2384
$$

And consequently, verification of inequality:

$$
2,2384>1,6449
$$

We deny null hypothesis and accept alternative hypothesis on the level of significance $\alpha=0.05$, that more than $30 \%$ of Slovak SMEs used financing through the bank overdraft in 2019.

Sample of Czech enterprises was not statistically relevant, so we increase the confidence interval on $6 \%$, so statistically relevant sample was 267 enterprises. The condition has been met and the test criterion was calculated as:

$$
T=\frac{0,2857-0,3}{\sqrt{\frac{0,3 *(1-0,3)}{350}}}=-0,5832
$$

And consequently, verification of inequality:

$$
-0,5832<-1,6449
$$

We accept null hypothesis on a level of significance $\alpha=0.05$, that $30 \%$ of Czech SME used financing through the bank overdraft in 2019. 
Sample of Hungarian enterprises was statistically relevant, the condition has been met and the test criterion was calculated as:

$$
T=\frac{0,2178-0,2}{\sqrt{\frac{0,2 *(1-0,2)}{450}}}=0,9428
$$

And consequently, verification of inequality:

$$
0,9428<-1,6449
$$

We don't deny null hypothesis on a level of significance $\alpha=0.05$ and accept that in 2019, 20\% of Hungarian SMEs used the bank overdraft as a source of financing.

Sample of Poland enterprises was statistically relevant, the condition has been met and the test criterion was calculated as:

$$
T=\frac{0,3951-0,4}{\sqrt{\frac{0,4 *(1-0,4)}{1091}}}=-0,3337
$$

And consequently, verification of inequality:

$$
-0,3337>1,6449
$$

We accept null hypothesis on a level of significance $\alpha=0.05$, that in $2019,40 \%$ of Polish small and medium-sized enterprises used an overdraft to finance their activities.

\section{Conclusions}

The aim of the study was a comparative analysis of forms of financing for small and medium-sized enterprises among the Visegrad Four countries with emphasis on alternative ways of finance. Based on the analysis of the available surveys we identify that the situation in the area of traditional financing through bank loans or leasing has not changed much in recent years. Although they are still one of the most used sources of financing, the high costs of using them force Hungarian companies in particular to use a different way of raising capital. The fact, that Hungarian SMEs does not use credit financing confirms the conclusion from hypothesis testing. Only one-fifth of the enterprises used bank overdraft as a source of finance in 2019. On the contrary, credit financing from bank overdraft is used the most in Poland, where this financing used $40 \%$ of SME in 2019.

Moreover, we found out that the use alternative forms of funding is even lower in V4 countries compared to other EU countries. Regarding the use of an alternative types of financing, such as venture capital, there has even been a decline in interest in this capital in recent years. The declining applicant may be caused by a team that is currently increasing technological and innovative start-ups, and the need for ever new ways of financing is also growing. Financing through business angels is experiencing great development, especially in Hungary. In addition, collective financing through crowdfunding based on equity shares, especially the Crowdberry platform, is experiencing the greatest success in Slovakia and the Czech Republic in which the Crowdberry platform.

The most favorable situation in the area of financing and the business environment is in Poland, but on the other side, Polish small and medium-sized enterprises lack innovation. From this point of view, Hungary has the highest potential, as an activity center for fastgrowing start-ups with innovative technologies. 


\section{References}

1. Allen, F., Chakrabarti, R., De, S., Qian, M. (2012). Financing firms in India. Journal of Financial Intermediation, 21(3), 409-445.

2. Ayyagari, M., Demirguc-Kunt, A., Maksimovic, V. (2014). Who creates jobs in developing countries? Small Business Economics, 43 (1), 75-99.

3. Arzayeva, M., Mustafina, A., Sadykhanova, G. (2019). 33rd IBIMA Conference. Granada. Available on the internet: https://ibima.org/accepted-paper/the-prospects-ofsmall-and-medium-sized-business-development-in-the-conditions-of-the-europeaneconomic-union/.

4. Balcerzak, A.P., Kliestik, T., Streimikiene, D., Smrcka, L. (2017). Non-Parametric approach to measuring the efficiency of banking sectors in European Union Countries. Acta Polytechnica Hungarica, 14(7), pp. 51-70.

5. Beck, T., Demirgüç-Kunt, A., Honohan, P. (2009). Access to financial services: Measurement, impact, and policies. The World Bank Research Observer, 24(1), 119145 .

6. Belas, J., Gavurova, B., Toth, P. (2018). Impact of selected characteristics of SMES on the capital structure. Journal of Business Economics and Management, 19(4), 592608 .

7. Belas, J., Gavurova, B., Cepel, M., Kubak, M. (2020). Evaluation of economic potential of business environment development by comparing sector differences: Perspective of SMEs in the Czech Republic and Slovakia. Oeconomia Copernicana, 11(1), 135-159.

8. Biswas, A. (2014). Financing constraints for SME sector. International Journal of Interdisciplinary and Multidisciplinary Studies, 1(5), 60-68.

9. Chong, T. T. L., Lu, L., Ongena, S. (2013). Does banking competition alleviate or worsen credit contraints faced by small- and medium- sized enterprises? Journal of Banking and Finance, 37(9), 3412-3424.

10. Hussain, J., Millman, C., Matlay, H. (2006). SME financing in the UK and in China: A comparative perspective. Journal of Small Business and Enterprise Development, 13(4), 5845-5899.

11. Kent Baker, H., Kumar, S., Rao, P. (2017). Financing preferences and practices of Indian SMEs. Global Finance Journal, Elsevier, 43(C).

12. Kramolis, J., Dobes, K. (2020). Debt as a financial risk factor in SMEs in the Czech Republic. Equilibrium. Quarterly Journal of Economics and Economic Policy, 15(1), 87-105.

13. Ryan, R., O’Toole, C., Mccann, F. (2014). Does bank market power affect SME financing constraints? Journal of Banking \& Finance, 49, 495-505.

14. Sham, P., Pang., I. (2014). China's SME development. OCBC Wing Hang Bank Monthly Newsletter. Available on the internet: https://www.ocbcwhhk.com/webpages_cms/files/Investment\%20Newsletter/English/I nvestment $\% 20$ Newsletter_Sep_e(1).pdf

15. Snijders, J., Van Der Horst, R., Isus, I., Lindeboom, G. J. (2016). SME promotion agencies: Is there a best set-up? A quest for good practices. Genova: International Labour Office.

16. Tian, Y., Nicholson, J. D., Eklinder-Frick, J., Johanson, M. (2018). The interplay between social capital and international opportunities: A processual study of 
international 'take-off' episodes in Chinese SMEs. Industrial marketing management, 70, 180-192. 